\title{
Equilibrium solubility versus intrinsic dissolution: characterization of lamivudine, stavudine and zidovudine for BCS classification
}

\author{
André Bersani Dezani, Thaisa Marinho Pereira, Arthur Massabki Caffaro, \\ Juliana Mazza Reis, Cristina Helena dos Reis Serra*
}

Department of Pharmacy, University of São Paulo, São Paulo, Brazil

\begin{abstract}
Solubility and dissolution rate of drugs are of major importance in pre-formulation studies of pharmaceutical dosage forms. The solubility improvement allows the drugs to be potential biowaiver candidates and may be a good way to develop more dose-efficient formulations. Solubility behaviour of lamivudine, stavudine and zidovudine in individual solvents (under $\mathrm{pH}$ range of 1.2 to 7.5 ) was studied by equilibrium solubility and intrinsic dissolution methods. In solubility study by equilibrium method (shake-flask technique), known amounts of drug were added in each media until to reach saturation and the mixture was subjected to agitation of $150 \mathrm{rpm}$ for 72 hours at $37^{\circ} \mathrm{C}$. In intrinsic dissolution test, known amount of each drug was compressed in the matrix of Wood's apparatus and subjected to dissolution in each media with agitation of $50 \mathrm{rpm}$ at $37{ }^{\circ} \mathrm{C}$. In solubility by equilibrium method, lamivudine and zidovudine can be considered as highly soluble drugs. Although stavudine present high solubility in $\mathrm{pH} 4.5,6.8,7.5$ and water, the solubility determination in $\mathrm{pH} 1.2$ was not possible due stability problems. Regarding to intrinsic dissolution, lamivudine and stavudine present high speed of dissolution. Considering a boundary value presented by Yu and colleagues (2004), all drugs studied present high solubility characteristics in intrinsic dissolution method. Based on the obtained results, intrinsic dissolution seems to be superior for solubility studies as an alternative method for biopharmaceutical classification purposes.
\end{abstract}

Uniterms: Drugs/solubility. Drugs/dissolution rate. Intrinsic dissolution/method/biopharmaceutical classification. Biopharmaceutical Classification System.

A solubilidade e a taxa de dissolução de fármacos são de grande importância em estudos de préformulação de formas farmacêuticas. A melhora na solubilidade permite que os fármacos sejam candidatos potenciais à bioisenção, podendo ser uma boa maneira para desenvolver formulações dose-eficientes. $\mathrm{O}$ comportamento de solubilidade da lamivudina, estavudina e zidovudina em solventes individuais (sob faixa de $\mathrm{pH} 1,2$ a 7,5) foi estudado pelos métodos de solubilidade em equilíbrio e dissolução intrínseca. No estudo de solubilidade pelo método do equilíbrio (método de agitação de frascos), conhecidas quantidades do fármaco foram adicionadas em cada meio até atingirem a saturação e a mistura foi submetida à agitação de $150 \mathrm{rpm}$ por 72 horas a $37^{\circ} \mathrm{C}$. No ensaio de dissolução intrínseca, conhecida quantidade de cada fármaco foi comprimida na matriz do aparato de Wood e submetida à dissolução em cada meio com agitação de $50 \mathrm{rpm}$ a $37^{\circ} \mathrm{C}$. No método de solubilidade em equilíbrio, a lamivudina e a zidovudina podem ser consideradas como fármacos altamente solúveis. Embora a estavudina apresente alta solubilidade nos meios pH 4,5, 6,8, 7,5 e água, a determinação da solubilidade em pH 1,2 não foi possível devido a problemas de estabilidade. Com relação à dissolução intrínseca, a lamivudina e a estavudina apresentaram alta velocidade de dissolução. Considerando o valor limite apresentado por Yu e colaboradores (2004), todos os fármacos apresentaram características de alta solubilidade no método de dissolução intrínseca. Com base nos resultados obtidos, a dissolução intrínseca parece ser superior para os estudos de solubilidade como um método alternativo para o propósito de classificação biofarmacêutica.

Unitermos: Fármacos/solubilidade. Fármacos/taxa de dissolução. Dissolução intrínseca/método/ classificação biofarmacêutica. Sistema de Classificação Biofarmacêutica.

\footnotetext{
*Correspondence: C. H. R. Serra. Departamento de Farmácia, Faculdade de Ciências Farmacêuticas, Universidade de São Paulo. Av. Prof. Lineu Prestes, n.580, 05508-000 - São Paulo - SP, Brasil. E-mail: chserra@usp.br; andredezani@usp.br
} 


\section{INTRODUCTION}

Biopharmaceutical Classification System (BCS) is a scientific tool proposed by Amidon and colleagues (1995) and it is based on aqueous solubility and intestinal permeability characteristics of drug substances. Thereby, the drugs can be classified into four classes: class I (high solubility and high permeability), class II (low solubility and high permeability), class III (high solubility and low permeability), and class IV (low solubility and low permeability) (Amidon et al., 1995; Lennernäs, Abrahamsson, 2005; Löbenberg, Amidon, 2000; United States, 2000).

The BCS is used to develop new pharmaceutical formulations, it assists in biowaiver processes for class I drugs as a regulatory tool and it predicts the in vivo behavior of a compound (Amidon et al., 1995; EMA, 2001; United States, 2000).

In 2000, a guide published by FDA (Food and Drug Administration), based on BCS, provides waiver for bioavailability and bioequivalence studies in vivo for immediate release dosage forms (class I drugs) (United States, 2000). Thus, it is possible to reduce time, costs and exposure of healthy volunteers to develop new medicinal products (Chen, Yu, 2009; Cook, Addicks, Wu, 2008; Lennernäs, 2007; Lennernäs, Abrahamsson, 2005; Lindenberg, Kopp, Dressman, 2004; Lobenberg, Amidon, 2000; United States, 2000).

For a biowaiver process, FDA guidance (2000) recommends solubility and permeability tests in order to classify drugs according to BCS (United States, 2000).

For permeability studies, several methods can be used to determine intestinal permeability of drugs such as: in situ intestinal perfusion in animals or humans (in vivo perfusion), in vitro permeation studies using artificial membranes or cell culture monolayers and ex vivo method using isolated intestinal segment (Dezani et al., 2013; Reis et al., 2013 United States, 2000).

The methods most recommended for solubility studies are: equilibrium method (shake-flask technique) and acid or base titration methods (employment must be justified). In the equilibrium solubility method, the evaluation of drug is achieved with the addition of an amount of substance in an aqueous solvent until it reaches the saturation of the media, followed by stirring for a prolonged period until the attainment of equilibrium (Avdeef, 2003; EMA, 2008; United States, 2000).

Solubility studies must be conducted under physiological $\mathrm{pH} 1.0$ - 7.5 according to FDA guidance, while for EMA (European Medicines Agency) the $\mathrm{pH}$ range should be between 1.2 and 6.8 , with test temperature of $37.0 \pm 1{ }^{\circ} \mathrm{C}$ (EMA, 2008; United States, 2000).

The solubility test allows to obtain the dose:solubility ratio, which corresponds to the ratio between the highest dose available in a pharmaceutical product and the solubility of the drug. Thus, according to FDA guidance, highly soluble drugs exhibit dose:solubility ratio less than $250 \mathrm{~mL}$ in a $\mathrm{pH}$ range of 1.0 to 7.5 at $37^{\circ} \mathrm{C}$ (Lindenberg, Kopp, Dressman, 2004; United States, 2000).

Other method for solubility studies, the intrinsic dissolution, has been used to characterize solid drugs (Amidon, Higuchi, Ho, 1982; Yu, Amidon, 1999; Yu et al., 2004; Zakeri-Milani et al., 2009). This property has been studied in order to elucidate the relationship between the dissolution rate and the crystalline form. In addition, it is possible to determinate a dissolution profile of a drug and also study the surfactants and $\mathrm{pH}$ effects on the dissolution of poorly soluble drugs (Chan, Grant, 1989; Dahlan, McDonald, Sunderland, 1987; Jinno et al., 2000; Wadke, Reier, 1972; Yu et al., 2004).

The intrinsic dissolution rate (IDR) is generally defined as the dissolution rate of a drug under constant surface area, stirring speed, $\mathrm{pH}$ and ionic strength of the dissolution media. The effective IDR is described as the rate of mass transferred from the solid surface to the liquid phase (Yu et al., 2004; Zakeri-Milani et al., 2009).

For the application of IDR and equilibrium methods for solubility studies, antiretroviral drugs were used in this study.

Lamivudine (3TC), stavudine (d4T) and zidovudine (AZT) are some examples of nucleoside reverse transcriptase inhibitors for HIV (Human Immunodeficiency Virus) treatment (Aymard et al., 2000; Balint, 2001; Checa et al., 2005). Solubility data related to these antiretroviral drugs are scarce in the literature.

Based on these conditions, the present study aims to evaluate the solubility behavior of 3TC, $\mathrm{d} 4 \mathrm{~T}$ and AZT using equilibrium solubility and intrinsic dissolution, and compare the results between these methods for BCS application, since steps such as disintegration and dissolution of a solid dosage form are crucial for drug release and subsequent absorption and bioavailability.

\section{MATERIAL AND METHODS}

\section{Buffers}

Four buffer solutions were prepared from different proportions of hydrochloric acid, monobasic potassium phosphate $(0.2 \mathrm{M})$ and sodium hydroxide (solution $0.2 \mathrm{M})$, as follows: $\mathrm{pH} 1.2(\mathrm{HCl}), \mathrm{pH} 4.5\left(\mathrm{KH}_{2} \mathrm{PO}_{4}\right), \mathrm{pH}$ $6.8\left(\mathrm{KH}_{2} \mathrm{PO}_{4}\right.$ and $\left.\mathrm{NaOH}\right)$, $\mathrm{pH} 7.5\left(\mathrm{KH}_{2} \mathrm{PO}_{4}\right.$ and $\left.\mathrm{NaOH}\right)$. High purity deionised water was obtained from 
Milli-Q purification system (Millipore, MA, USA) and used for components dissolution. The $\mathrm{pH}$ values were adjusted using $\mathrm{HCl} 0.1 \mathrm{M}$ and $\mathrm{NaOH} 0.2 \mathrm{M}$ solutions.

All dissolution media were prepared according to USP XXXIII, British Pharmacopoeia and Portuguese Pharmacopeia IX (British Pharmacopoeia, 2009; Farmacopéia Portuguesa IX, 2008; United States Pharmacopeia, 2010).

\section{Equilibrium solubility method (shake-flask)}

Solubility studies of antiretroviral drugs were determined by equilibrating excess amount of each drug in buffer solutions of $\mathrm{pH} 1.2,4.5,6.8,7.5$ and purified water.

Assays were performed in plastic flasks with a capacity of $50 \mathrm{~mL}$. In each flask were added $10 \mathrm{~mL}$ of media and the amount of drug separately. The amount was sufficient to saturate each media, which was characterized by depositing of substance not solubilized.

Incubator shaker was used to keep samples at $37^{\circ} \mathrm{C}$ during the test with agitation of $150 \mathrm{rpm}$ for 72 hours (until achieve the equilibrium condition) (Marín, Margarit, Salcedo, 2002; Okumu, Dimaso, Löbenberg, 2009; United States, 2000; Won et al., 2005). After this period, samples were immediately filtered $(0.45 \mu \mathrm{m})$ and diluted in a volumetric flask with the corresponding media.

For quantification processes of antiretroviral drugs, a UV-Vis spectrophotometer (Varian) was used at maximum absorbance wavelength for each media and the solubility values were calculated using calibration curves determined for each substance.

With solubility results, the dose:solubility ratio was calculated, which is obtained by dividing the highest commercially available dose of the drug (in milligrams) by the solubility (in milligrams per milliliter) obtained in the study. The values of the dose:solubility ratio are then compared with the criteria established by the FDA guidance to verify if the drug is highly soluble or not (Lindenberg, Kopp, Dressman, 2004; United States, 2000).

\section{Intrinsic dissolution method}

Two types of apparatus are described for intrinsic dissolution tests: a fixed-disk system and a rotating-disk system (Wood's apparatus) (British Pharmacopoeia, 2009; European Pharmacopoeia, 2008; United States Pharmacopeia, 2010; Viegas et al., 2001).

Dissolution studies were conducted using the Wood's apparatus, which was originally developed by John Wood and enables the calculation of the dissolution rate per square centimeter (Wood, Syarto, Letterman, 1965; Yu et al., 2004; Zakeri-Milani et al., 2009).

During the intrinsic dissolution method development, the antiretroviral drugs were subjected to different compression force until define the optimal compression force. Previous intrinsic dissolution tests indicate that there were no changes in the dissolution profiles, indicating absence of a polymorphic transition. The compression force used was sufficient to form the drug disk, which remained stable until its complete dissolution in the media. According to $\mathrm{Yu}$ and colleagues (2004), the intrinsic dissolution method presents robustness and it is not influenced by compression force, dissolution volume, distance of the drug disk from the bottom of the dissolution vessel, and drug disk rotation speed (Yu et al., 2004).

An amount of drug was compressed to make a non-disintegrating disk and the exposed surface area was $0.5 \mathrm{~cm}^{2}$. Table I summarizes the conditions used to obtain disks for intrinsic dissolution studies for each drug.

For each assay, three vessels were previously filled with $900 \mathrm{~mL}$ of buffer solution at a temperature of $37.0 \pm 0.5^{\circ} \mathrm{C}$ with rotation of $50 \mathrm{rpm}$. Samples were withdrawn at 2, 4, 6, 8, 10, 12, 14, 16, 18, 20, 25, 30, 35, $40,45,50,55,60,70$ and 80 min with replacement of fresh media. To highly soluble drugs, it was necessary to withdraw a known aliquot from the dissolution media and make a volumetric dilution before determining absorbance values by UV-spectroscopy (United States Pharmacopeia, 2010; Yu et al., 2004). It is important to consider that the solution containing a compound with low solubility and high molar absorptivity may be diluted, as solution containing a compound with high solubility and low molar absorptivity may not be necessarily diluted. Thus, the dilution mainly depends on molar absorptivity of the drugs (Alves et al., 2010; Filippin, Souza, 2006; Pereira et al., 2011; Ruela, Araújo, Pereira, 2009).

TABLE I - Conditions adopted for each antiretroviral drug to obtain disks for intrinsic dissolution study

\begin{tabular}{lccc}
\hline drug & compressed amount $(\mathrm{mg})$ & time of compression $(\mathrm{min})$ & pressure $(\mathrm{psi})$ \\
\hline 3 TC & 300 & 3 & 3000 \\
d4T & 350 & 2 & 2000 \\
AZT & 200 & 1 & 2000 \\
\hline
\end{tabular}


The cumulative quantity of dissolved drug was corrected for each sample interval according to volume collected from the each vessel. For IDR values, a graph was constructed through accumulated amount of the drug dissolved versus time and a linear regression was performed. Thus, the dissolution rate was obtained (Issa, Ferraz, 2011).

Absorbance values were determined in triplicate at the maximum absorbance wavelength. The amount dissolved per surface unit of the disk was plotted against the time for each dissolution vessel. The slope of the linear regression $\left(R^{2} \geq 0,99, p<0,005\right)$ was considered as IDR, which can be calculated by equation below:

$$
j=\frac{V d c}{d t} \frac{1}{A}
$$

where $j$ is the disk intrinsic dissolution rate, $V$ is the volume of the dissolution media, $c$ is the drug concentration, $A$ is the disk area, and $t$ is the time (Yu et al., 2004).

\section{RESULTS AND DISCUSSION}

\section{Equilibrium solubility method (shake-flask)}

In order to set a reliable condition for BCS classification of compounds and considering that small intestine is the major site for drug absorption, this study has considered the $\mathrm{pH}$ range of 1.2 to 7.5 for equilibrium solubility and intrinsic dissolution studies.

Based on solubility results, it is possible calculate the dose:solubility ratio, which represents a volume of media necessary to solubilize the highest dose of the administered drug. An API (active pharmaceutical ingredient) is considered highly soluble when the dose:solubility ratio is less than $250 \mathrm{~mL}$ (Lindenberg, Kopp, Dressman, 2004; United States, 2000) in a pH range of 1.0 to 7.5 (United States, 2000) or pH 1.2 to 6.8 (EMA, 2008; WHO, 2005) at $37^{\circ} \mathrm{C}$ (Strauch et al., 2011).

However, differences may exist in relation to the dosages of the drug, depending on the country and adopted protocols, which can determine variability in the biopharmaceutical classification of a compound. For example, due to the higher dose available for a medicinal product, the same active substance may be considered as high solubility drug in a country and low solubility drug in another country (Lindenberg, Kopp, Dressman, 2004; United States, 2012; WHO, 2005).

During equilibrium solubility test of d4T, the buffer solution $\mathrm{pH} 1.2$ showed, at the end of the test, changes in smell and color, suggesting a possible degradation reaction due the test conditions ( $150 \mathrm{rpm} 37^{\circ} \mathrm{C}$ for 72 hours), thus making it impossible to obtain results of solubility in this media.

Studies conducted by Silva and colleagues (2008) have reported that the main degradation product of $\mathrm{d} 4 \mathrm{~T}$ is thymine. This product is mainly formed after hydrolytic and oxidative processes (Silva et al., 2008).

Table II shows solubility results (in $\mathrm{mg} \mathrm{mL}^{-1}$ ) and dose:solubility ratio (in $\mathrm{mL}$ ) for antiretroviral drugs and the Figure 1 represents average solubility of 3TC, d4T and AZT, respectively.

The recommended dose for $3 \mathrm{TC}$ is $300 \mathrm{mg}$, for $\mathrm{d} 4 \mathrm{~T}$ is $40 \mathrm{mg}$ and for AZT is $300 \mathrm{mg}$. These substances are clearly classified as high solubility drugs at $\mathrm{pH} 1.2$, $4.5,6.8,7.5$ and water (except $\mathrm{d} 4 \mathrm{~T}$, where solubility in $\mathrm{pH} 1.2$ was not possible), since they satisfy the criteria of dose:solubility ratio $<250 \mathrm{~mL}$, as demonstrated in Table II (United States, 2000; United States, 2012; WHO, 2006).

The results of solubility indicate that $3 \mathrm{TC}$ and AZT present high solubility characteristics based on FDA criteria. By the other hand, d4T presents high solubility in water, $\mathrm{pH} 4.5, \mathrm{pH} 6.8, \mathrm{pH} 7.5$, but the solubility determination of $\mathrm{d} 4 \mathrm{~T}$ was not possible at $\mathrm{pH} 1.2$ due to stability problems in this media. Thus, the solubility is not a limiting factor for bioavailability of $3 \mathrm{TC}$ and AZT (United States, 2000).

The stability problems can be identified through differences in the smell and color of the solution prepared. In the case of $\mathrm{d} 4 \mathrm{~T}$, a difference in the smell and color of the solution was noticed but for some drugs these differences may not be evident. To ensure the integrity of the drugs solubilized in the different media studied, the antiretroviral drugs were subjected to a stability assay and the quantification was performed using a chromatographic method (HPLC system Merck-Hitachi LaChrom ${ }^{2}$, USA).

The stability assay was performed for each drug in each media with different $\mathrm{pH}$ values. Briefly, the solutions were subjected to the conditions of the solubility assay considering the time and the temperature. The total time of the stability assay was 72 hours at $37^{\circ} \mathrm{C}$. Analyses of the solutions were performed at 12, 24, 36, 48, 72 hours and the results were compared to standard solutions of the drugs freshly prepared. The chromatograms of the drugs were equivalent to standard solution of the drugs for 3TC, AZT and d4T, except for $\mathrm{pH} 1.2$, where the chromatograms indicate significant differences for stavudine.

Solubility data from literature about $3 \mathrm{TC}$, d4T and AZT are not easily found. The few existing reports show differences that can be justified by: technique or type of test used, temperature, composition and $\mathrm{pH}$ of the media.

According to Merck Index (2001), the solubility of 3TC is $70.0 \mathrm{mg} \mathrm{mL}^{-1}$ (at $20^{\circ} \mathrm{C}$ ) and for AZT is $25.0 \mathrm{mg} \mathrm{mL}^{-1}$ 
TABLE II - Solubility at $37^{\circ} \mathrm{C}$ and dose:solubility ratio of 3TC, d4T and AZT for each media used obtained through equilibrium method

\begin{tabular}{|c|c|c|c|c|}
\hline Drug and dose & $\mathrm{pH}$ & wavelength (nm) & solubility $\left(\mathrm{mg} \mathrm{mL}^{-1}\right)$ & dose:solubility ratio* $(\mathrm{mL})$ \\
\hline \multirow{3}{*}{ 3TC (300 mg) } & 4.5 & 275 & 155.95 & 1.92 \\
\hline & 7.5 & 273 & 190.70 & 1.57 \\
\hline & water & 272 & 177.53 & 1.69 \\
\hline \multirow{3}{*}{$\overline{\mathrm{d} 4 \mathrm{~T}(40 \mathrm{mg})}$} & 6.8 & 266 & 139.43 & 0.29 \\
\hline & 7.5 & 266 & 130.15 & 0.31 \\
\hline & water & 266 & 146.49 & 0.27 \\
\hline \multirow[t]{2}{*}{ AZT (300 mg) } & 1.2 & 268 & 18.65 & 16.08 \\
\hline & water & 267 & 25.39 & 11.82 \\
\hline
\end{tabular}

* Dose:solubility ratio $\leq 250$ indicates high solubility related to dose (United States, 2000)

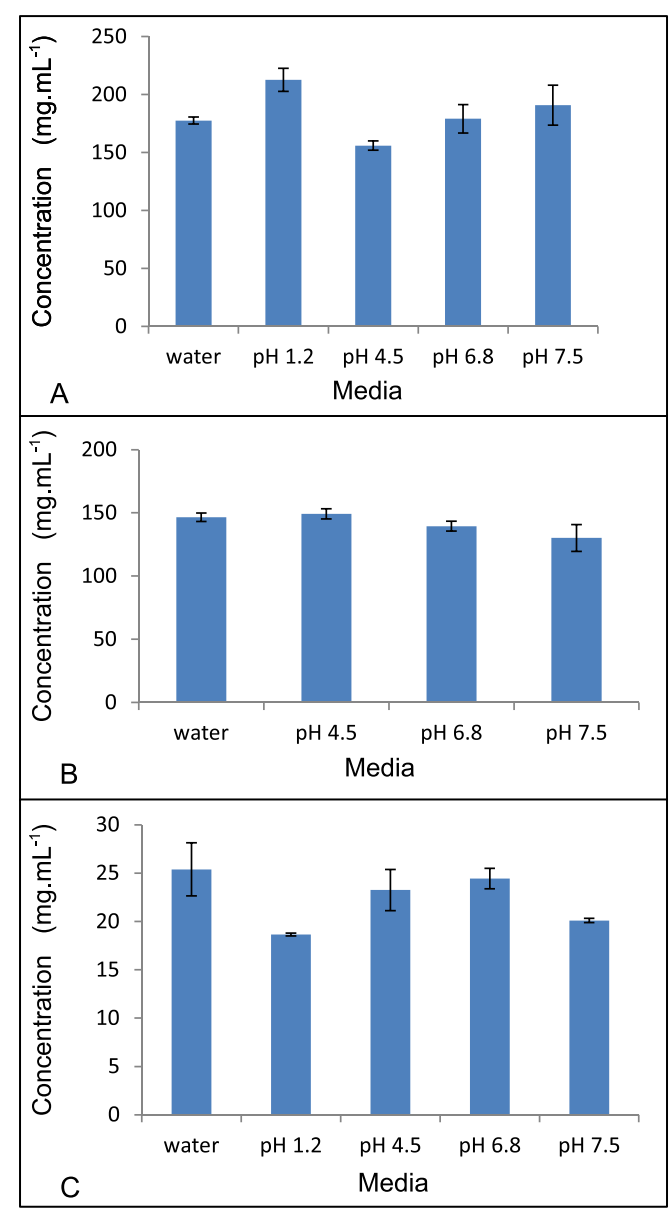

FIGURE 1 - Average solubility of 3TC (A), d4T (B) and AZT (C) in water, $\mathrm{pH} 1.2$ (except $\mathrm{d} 4 \mathrm{~T}), \mathrm{pH} 4.5, \mathrm{pH} 6.8$ and $\mathrm{pH}$ 7.5. (at $25^{\circ} \mathrm{C}$ ). The results presented in this study are different from Merck Index, but test conditions such as temperature and method can justify theses differences. The temperature is a crucial factor, since that this parameter can influence the solubility, i.e., if temperature increases, the drug solubility is higher (Merck Index, 2001). It is important to note that this study followed FDA recommendations.

Singh and colleagues determined the equilibrium solubility of AZT in water and in phosphate buffer $\mathrm{pH} 6.8$ employing the technique of shake-flask under stirring for 48 hours at temperatures of $37^{\circ} \mathrm{C}$ and $25^{\circ} \mathrm{C}$. The results indicated that AZT had a solubility of $30.6 \mathrm{mg} \mathrm{mL}^{-1}$ at $37{ }^{\circ} \mathrm{C}$ and $19.5 \mathrm{mg} \mathrm{mL}^{-1}$ at $25^{\circ} \mathrm{C}$ in water. In phosphate buffer $\mathrm{pH} 6.8$, the solubility was $24.4 \mathrm{mg} \mathrm{mL}^{-1}$ at $37^{\circ} \mathrm{C}$ and $20.3 \mathrm{mg} \mathrm{mL}^{-1}$ at $25^{\circ} \mathrm{C}$. AZT results of this study are in accordance to results presented by Singh and colleagues (2010) (Singh et al., 2010).

In another study, Prakash and colleagues (2008) examined the solubility of antiretroviral drugs, 3TC, d4T and AZT, in different media (purified water, 0.01 $\mathrm{M} \mathrm{HCl}$ solution, acetate buffer $\mathrm{pH} 4.5$ and phosphate buffer $\mathrm{pH}$ 6.8). The results obtained by these authors are presented in Table III.

The results described in this work are different than those indicated and published by Prakash and colleagues (2008). Such differences can be attributed to conditions employed for the solubility determination, such as: temperature, intensity and kind of stirring, test time, composition of the dissolution media. 
TABLE III - Solubility values obtained from literature (Prakash et al., 2008)

\begin{tabular}{lcccc}
\hline \multicolumn{5}{c}{ Solubility $\left(\mathrm{mg} \mathrm{mL}^{-1}\right)$} \\
\hline 3TC & water & HCl $0.01 \mathrm{M}$ & $\mathrm{pH} 4.5$ (acetate buffer) & $\mathrm{pH} \mathrm{6.8} \mathrm{(phosphate} \mathrm{buffer)}$ \\
d4T & 140.01 & 276.08 & 230.50 & 92.76 \\
AZT & 75.36 & 78.19 & 101.23 & 76.13 \\
\hline
\end{tabular}

As explained above, the solubility determination of 3TC, d4T and AZT in the present study was performed according to FDA guidance (United States, 2000) in an incubator with orbital shaking platform. This equipment enables the heating of flasks and adequate control of the temperature (maintained at $37.0 \pm 0.5^{\circ} \mathrm{C}$ ). Moreover, the orbital shaking platform promotes speed control (150 rpm). Thus, the conditions adopted in this study remained constant and standardized. The stirring time used in this work was 72 hours, which is important period to reach the saturation of the media.

Furthermore, in studies conducted by Prakash and colleagues (2008), the heating of media was located not ensuring proper distribution of temperature, and stirring was promoted using a magnetic stirrer. It should be noted also that the total test time for the cited study was 5 hours. Another factor is the dissolution media composition (Prakash et al., 2008).

\section{Intrinsic dissolution method}

Intrinsic dissolution has been recently studied and discussed for solubility determination of a compound as an alternative method to equilibrium solubility. Values of intrinsic dissolution rate can be used to determine the solubility class of a drug (Issa, Ferraz, 2011; Yu et al., 2004; Zakeri-Milani et al., 2009).

The standardization of intrinsic dissolution test should be made carefully because this method is influenced by internal and external factors (properties of solid state, surface area, hydrodynamic condition, composition of dissolution media, vibration, rotation speed, presence of dissolved gases in dissolution media, sample sites) (Issa, Ferraz, 2011; Souza, Freitas, Storpirtis, 2007). Thus, all these conditions were controlled and standardized to minimize any interference.

Figure 2 shows a typical plot of amount of drug versus time for 3TC, d4T and AZT at different values of $\mathrm{pH}$ and water. The insignificant discrepancies between three runs using three disks in three dissolution vessels indicate an excellent reproducibility (RSD less than 10\%). Linearity was also excellent, which can be demonstrated by a correlation coefficient higher than 0.99 for all solutions used.

From the dissolution profiles were obtained intrinsic dissolution rates (IDR). The IDR speed of the sample is determined from the slope of the line (United States Pharmacopeia, 2010).

The determined IDR for each drug are shown in Table IV. The presence of a sink condition in the dissolution media during the experiment is upheld by comparison of the final concentration of drugs and their solubility in dissolution media.

IDR results showed in Table IV demonstrate a good

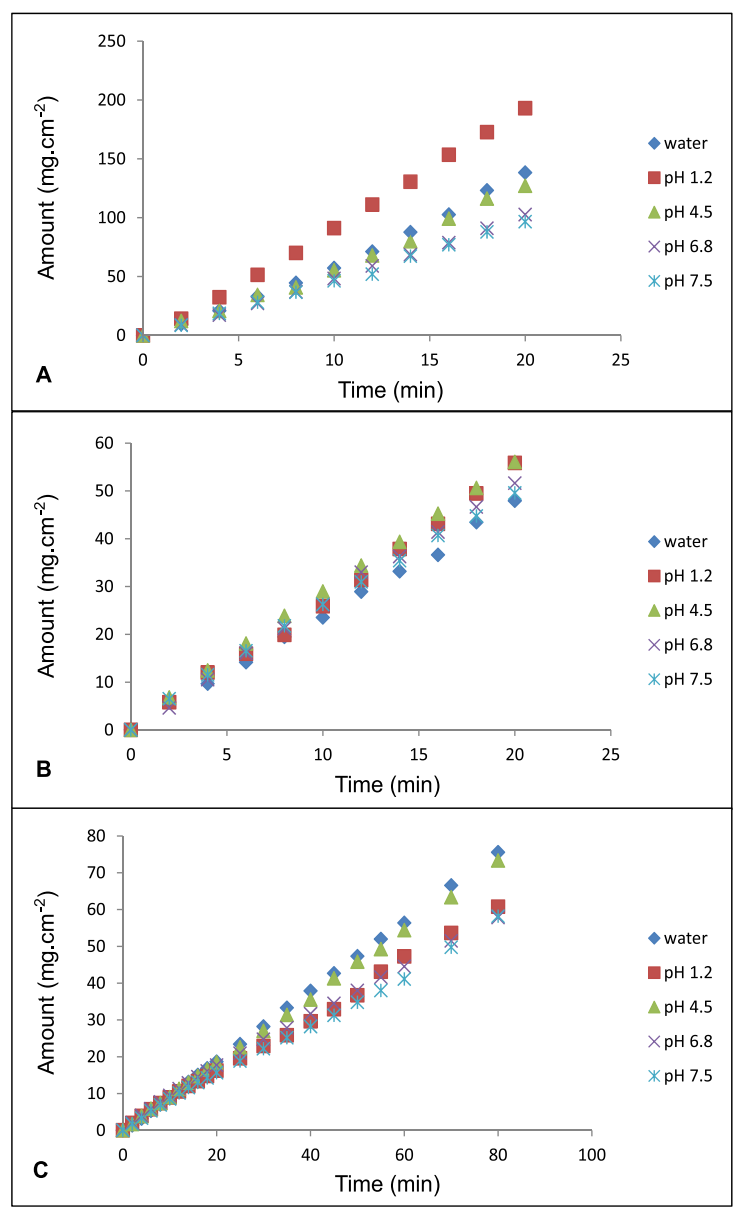

FIGURE 2 - Amount versus time profile for 3TC (A), d4T (B) and AZT (C) at $\mathrm{pH}$ values of 1.2, 4.5, 6.8, 7.5 and water. 
TABLE IV - Intrinsic dissolution rate (IDR) of 3TC, d4T and AZT.

\begin{tabular}{lccccc}
\hline \multirow{2}{*}{ drug } & \multicolumn{5}{c}{$\operatorname{IDR}\left(\mathrm{mg} \mathrm{min}^{-1} \mathrm{~cm}^{-2}\right)$} \\
\cline { 2 - 6 } & $\mathrm{pH} 1.2$ & $\mathrm{pH} \mathrm{4.5}$ & $\mathrm{pH} \mathrm{6.8}$ & $\mathrm{pH} \mathrm{7.5}$ & water \\
\hline 3TC & 9.83 & 6.38 & 5.13 & 4.86 & 6.94 \\
d4T & 2.74 & 2.76 & 2.59 & 2.43 & 2.36 \\
AZT & 0.74 & 0.90 & 0.72 & 0.66 & 0.95 \\
\hline
\end{tabular}

qualitative correlation with the equilibrium solubility. IDR is a rate phenomenon instead of an equilibrium phenomenon. In addition, IDR values correlate more closely with in vivo drug dissolution dynamics than equilibrium solubility because dose recommended is taken into account in this method while the intrinsic dissolution does not consider this effect (Issa, Ferraz, 2011).

Thus, when the drug dose is extremely high or extremely low (for exemple $1.0 \mathrm{mg} \mathrm{mL}^{-1}$ and recommended dose of $0.25 \mathrm{mg}$ or $4.0 \mathrm{mg} \mathrm{mL}^{-1}$ and recommended dose of $1000 \mathrm{mg}$ ) a discrepancy between the equilibrium solubility and the IDR may occur. Further, when the drug dose is extremely high, the in vivo absorption may be limited by solubility (Singh et al., 2010).

At least 10 points were used for the construction of intrinsic dissolution profiles of drugs. Due to the high rate of dissolution, short intervals were imposed to reach sampling points and obtain meaningful results. 3TC and d4T presented higher dissolution speed compared to AZT, which takes a longer time to reach $10 \%$ of dissolution (United States Pharmacopeia, 2010).

As regard to IDR, it is noteworthy that there are no reports in the literature about the intrinsic characteristics of antiretroviral drugs dissolution but it possible to find limits to characterize high soluble drugs.

According to Yu and colleagues (2004), compounds which have IDR greater than $0.1 \mathrm{mg} \mathrm{min} \mathrm{m}^{-1} \mathrm{~cm}^{-2}$ can be classified as highly soluble substances. Based on this information, all antiretroviral drugs studied can be classified as highly soluble compounds in all dissolution media due to IDR values higher than $0.1 \mathrm{mg} \mathrm{min} \mathrm{m}^{-1}$ (Yu et al., 2004).

Another study developed by Zakeri-Milani and colleagues (2009) suggests that drugs with IDR value higher than $1 \mathrm{mg} \mathrm{min}^{-1} \mathrm{~cm}^{-2}$ can be considered as highly soluble substances, while compounds with low solubility show an IDR value lower than $1 \mathrm{mg} \mathrm{min}^{-1} \mathrm{~cm}^{-2}$ (ZakeriMilani et al., 2009).

\section{Equilibrium solubility versus intrinsic dissolution}

In recent years, solubility and permeability studies have received focus from scientific community due to BCS and, consequently FDA guidance for biowaiver purposes. Thereby, comparison between equilibrium solubility and intrinsic dissolution methods has been grown, since that solubility is a crucial factor for the absorption (and bioavailability) of drugs.

Equilibrium solubility presents some factors that can difficult the achievement of results, such as: temperature, filtration processes, substance characteristics (as crystalline structure or salts formation) (Baka, Comer, Takács-Novak, 2008; Issa, Ferraz, 2011; Yu et al., 2004). However, this does not allow obtain a solubility profile of drugs or identify their amorphous because it is an equilibrium condition that must not be interfered during the test (sampling is not possible), otherwise result in the impairment of reliable data (Issa, Ferraz, 2011).

Although equilibrium solubility method adopts physiological conditions as temperature and solution $\mathrm{pH}$, other aspects must be observed. The temperature is a factor that interferes a lot in this test and the loss of temperature can cause the appearance of crystals and loss of equilibrium condition, compromising results. The intrinsic dissolution test, the same temperature and solutions are used but it is a safer method because the loss of temperature causes no major influences compared to equilibrium test because the dissolution media is not saturated.

In addition, the test time is too long (until 72 hours) in equilibrium method and the amount of drug used for this study is very high compared to intrinsic dissolution, which requires a less amount of drug (which is suitable for the early stages of development of new compounds). A less amount of drug in intrinsic solution allows realize any interference in the results due to factors such as any change in crystalline structure or salts formation characterized by deviation from linearity (Issa, Ferraz, 2011; Yu et al., 2002; Yu et al., 2004; Zakeri-Milani et al., 2009).

The conditions of amount of drug and dissolution media volume deviate from the in vivo condition because the administered drug does not remain so long in the dissolution step in the stomach and the substance does not saturate the dissolution media in vivo. In intrinsic dissolution, the volume of dissolution media is major than equilibrium method and the dissolution of drug is constant and linear.

This is an important point to be discussed and more deeply studied. Based on d4T results obtained in this study, intrinsic dissolution allowed the solubility study, whereas in equilibrium study the determination of solubility was not possible due to degradation suffered by this drug. The media volume of buffer and no saturation of dissolution media indicate that intrinsic dissolution can be used to study the behavior of sensitive drugs. 


\section{CONCLUSION}

The BCS was developed based on two properties: solubility/dissolution rate and intestinal permeability of drugs. In this study, 3TC, d4T and AZT were assessed by two methods for solubility study: equilibrium solubility and intrinsic dissolution. Based on results, 3TC and AZT present high solubility characteristics in equilibrium solubility, which was confirmed by intrinsic dissolution (high speed of dissolution). The solubility determination of $\mathrm{d} 4 \mathrm{~T}$ in $\mathrm{pH} 1.2$ was not possible due to stability problems in equilibrium solubility method. Based on FDA criteria, a drug must be soluble in a $\mathrm{pH}$ range of $1.0-7.5$ at $37^{\circ} \mathrm{C}$ and the $\mathrm{d} 4 \mathrm{~T}$ does not match this criteria. By the other hand, d4T did not present any inconvenience in intrinsic dissolution method and $\mathrm{d} 4 \mathrm{~T}$ presents high speed of dissolution as 3TC and AZT.

According to discussed in this study, IDR has demonstrate adequate method for solubility studies instead equilibrium solubility method, since these method does not consider dose effect of drug. Thus, the behavior of drugs can be predicted through IDR because this method is closest to in vivo conditions.

Yu and colleagues (2004) consider $0.1 \mathrm{mg} \mathrm{min}^{-1} \mathrm{~cm}^{-2}$ as a boundary value, while Zakeri-Milani and colleagues (2009) consider $1.0 \mathrm{mg} \mathrm{min}^{-1} \mathrm{~cm}^{-2}$ for classification of a drug according to their intrinsic solubility. Then, based on Yu and colleagues, 3TC, d4T and AZT may be considered as highly soluble drugs. On the other hand, when the boundary value proposed by Zakeri-Milani and colleagues is considered, 3TC and d4T may be considered as highly soluble drugs, while AZT may be considered a compound of low solubility.

According to FDA, a criterion which is based on Biopharmaceutical Classification System, AZT is classified as highly soluble drug (Soares et al., 2013), since the equilibrium method is employed for solubility studies. As intrinsic dissolution is not yet used for regulatory purposes, this study aimed to discuss the feasibility of this technique and once appropriately standardized, may be accept as an alternative methodology for equilibrium solubility assay of drugs. Moreover, the intrinsic dissolution is a rate phenomenon, different from the equilibrium solubility (Yu et al., 2004; Zakeri-Milani et al., 2009).

Due to great diversity of drugs with different physicochemical characteristics, a limit value is difficult to be purpose and it depends on data and more consistent studies, as discussed by Yu and colleagues (2004). The establishment of a boundary value for intrinsic dissolution is still considered a challenge, which is being explored by researchers and the results of these studies are being published in the literature.

In this study, we emphasize that conditions adopted to obtain intrinsic dissolution results is in according to conditions described in the study published by $\mathrm{Yu}$ and colleagues (2004), where variables were evaluated, determining the robustness of the method.

In summary, the data obtained from the intrinsic dissolution test confirm the results obtained in equilibrium solubility when a boundary value of $0.1 \mathrm{mg} \mathrm{min} \mathrm{m}^{-1} \mathrm{~cm}^{-2}$ is considered and the drugs can be classified as highly soluble substances, as proposed by Yu and colleagues (2004) (Yu et al., 2004). Based on the boundary value $\left(1 \mathrm{mg} \mathrm{min}^{-1} \mathrm{~cm}^{-2}\right)$ proposed by Zakeri-Milani and colleagues (2009), 3TC and $\mathrm{d} 4 \mathrm{~T}$ can be classified as highly soluble drugs, while AZT would be considered as low solubility drug (ZakeriMilani et al., 2009).

\section{ACKNOWLEDGMENTS}

The authors wish to thank the Conselho Nacional de Desenvolvimento Científico e Tecnológico (CNPq, Brazil), Fundação de Amparo à Pesquisa do Estado de São Paulo (FAPESP, Brazil) and Coordenação de Aperfeiçoamento de Pessoal de Nível Superior (CAPES, Brazil) for financial support and Fundação para o Remédio Popular (FURP, Brazil) and Cristália Produtos Químicos Farmacêuticos for donation of chemicals substances (lamivudine, stavudine and zidovudine).

\section{REFERENCES}

ALVES, L.D.S.; ROLIM, L.A.; FONTES, D.A.F.; ROLIMNETO, P.J. Desenvolvimento de método analítico para quantificação do efavirenz por espectrofotometria no UVVIS. Quím. Nova, v.33, n.9, p.1967-1972, 2010.

AMIDON, G.L.; HIGUCHI, W.I.; HO, N.F. Theoretical and experimental studies of transport of micelle-solubilized solutes. J. Pharm. Sci., v.71, p.77-84, 1982.

AMIDON, G.L.; LENNERNÄS, H.; SHAH, V.P.; CRISON, J.R. A theoretical basis for a biopharmaceutic drug classification: the correlation of in vitro drug product dissolution and in vivo bioavailability. Pharm. Res., v.12, n.3, p.413-420, 1995.

AVDEEF, A. Absorption and drug development: solubility, permeability and charge state. Hoboken: Wiley Interscience, 2003. 287 p. 
AYMARD, G.; LEGRAND, M.; TRICHEREAU, N.; DIQUET, B. Determination of twelve antiretroviral agents in human plasma sample using reversed-phase high-performance liquid chromatography. J. Chromatogr. B Biomed. Sci. Appl., v.744, n.2, p.227-240, 2000.

BALINT, G.A. Antiretroviral therapeutic possibilities for human immunodeficiency virus/acquired immunodeficiency syndrome. Pharmacol. Ther., v.89, n.1, p.17-27, 2001.

BAKA, E.; COMER, J.E.; TAKÁCS-NOVÁK, K. Study of equilibrium solubility measurement by saturation shakeflask method using hydroclorothiazide as model compound. J. Pharm. Biomed. Anal., v.46, n.2, p.335-341, 2008.

BRITISH Pharmacopoeia. London: Her Majesty’s Stationary Office, 2009. A768 p.

CHAN, H.-K.; GRANT, D.J.W. Influence of compaction on the intrinsic dissolution rate of modified acetaminophen and adipic acid crystals. Int. J. Pharm., v.57, n.2, p.117124, 1989.

CHECA, A.; SOTO, V.G.; HERNÁNDEZ-CASSOU, S.; SAURINA, J. Fast determination of $\mathrm{p} K$ a values of reverse transcriptase inhibitor drugs for AIDS treatment by using $\mathrm{pH}$-gradient flow-injection analysis and multivariate curve resolution. Anal. Chim. Acta, v.554, n.1-2, p.177-183, 2005.

CHEN, M.-L.; YU, L. The use of drug metabolism for prediction of intestinal permeability. Mol. Pharm., v.6, n.1, p.74-81, 2009.

COOK, J.; ADDICKS, W.; WU, Y.H. Application of the biopharmaceutical classification system in clinical drug development: an industrial view. AAPS J., v.10, n.2, p.306310, 2008.

DAHLAN, R.; MCDONALD, C.; SUNDERLAND, V.B. Solubilities and intrinsic dissolution rates of sulphamethoxazole and trimethoprim. J. Pharm. Pharmacol., v.39, n.4, p.246-251, 1987.

DEZANI, A.B.; PEREIRA, T.M.; CAFFARO, A.M.; REIS, J.M.; SERRA, C.H.R. Determination of lamivudine and zidovudine permeability using a different ex vivo method in Franz cells. J. Pharmacol. Toxicol. Methods, v.67, p.194-202, 2013.
EUROPEAN MEDICINES AGENCY. Evaluation of medicines for human use. Committee for proprietary medicinal products. Note for guidance on the investigation of bioavailability and bioequivalence. London, 2001. (CPMP/EWP/QWP/1401/98). Available at: <http://www. ema.europa.eu/docs/en_GB/document_library/Scientific guideline/2009/09/WC500003519.pdf $>$. Accessed on: 20 Aug 2012.

EUROPEAN MEDICINES AGENCY. Pre-Authorization Evaluation of Medicines for Human Use. Committee for Medicinal Products for Human Use. DRAFT: Guideline on the investigations of bioequivalence. London, 2008. (CPMP/EWP/QWP/1401/98). Available at: <http://www. emea.europa.eu/docs/en_GB/document_library/Scientific guideline/2009/09/WC500003011.pdf>. Accessed on: 16 Aug 2012.

EUROPEAN Pharmacopoeia. 6.ed. France: European directorate for the quality of medicines. Strasbourg: Council of Europe, 2008. p.309-211

FARMACOPÉIA Portuguesa IX. Lisboa: Infarmed/Ministério da Saúde e Instituto Nacional da Farmácia e do Medicamento, 2008. 3827 p.

FILIPPIN, F.B.; SOUZA, L.C. Eficiência terapêutica das formulações lipídicas de anfotericina B. Rev. Bras. Ciênc. Farm., v.42, n.2, p.167-194, 2006.

ISSA, M.G.; FERRAZ, H.G. Intrinsic dissolution as a tool for evaluating drug solubility in accordance with the biopharmaceutics classification system. Dissolut. Technol., v.18, n.3, p.6-13, 2011.

JINNO, J.; OH, D.-M.; CRISON, J.R.; AMIDON, G.L. Dissolution of ionizable water-insoluble drugs: the combined effect of $\mathrm{pH}$ and surfactant. J. Pharm. Sci., v.89, n.2, p.268-274, 2000.

LENNERNÄS, H. Animal data: the contributions of the Ussing chamber and perfusion systems to predicting human oral drug delivery in vivo. Adv. Drug Deliv. Rev., v.59, n.11, p.1103-1120, 2007.

LENNERNÄS, H.; ABRAHAMSSON, B. The use of biopharmaceutic classification of drugs in drug discovery and development: current status and future extension. $J$. Pharm. Pharmacol., v.57, n.3, p.273-285, 2005. 
LINDENBERNG, M.; KOPP, S.; DRESSMAN, J.B. Classification of orally administered drugs on the World Health Organization model list of essential medicines according to the biopharmaceutics classification system. Eur. J. Pharm. Biopharm., v.58, n.2, p.265-278, 2004.

LÖBENBERG, R.; AMIDON, G.L. Modern bioavailability, bioequivalence and biopharmaceutics classification system. New scientific approaches to international regulatory standards. Eur. J. Pharm. Biopharm., v.50, n.1, p.3-12, 2000.

MARÍN, M.T.; MARGARIT, M.V.; SALCEDO, G.E. Characterization and solubility study of solid dispersions of flunarizine and polyvinylpyrrolidone. Farmaco, v.57, n.9, p.723-727, 2002.

MERCK index: an encyclopedia of chemicals, drugs and biologicals. 13.ed. Whitehouse Station: Merck, 2001. p.959-1802.

OKUMU, A.; DIMASO, M.; LÖBENBERG, R. Computer simulations using Gastroplus ${ }^{\mathrm{TM}}$ to justify a biowaiver for etoricoxib solid oral drug products. Eur. J. Pharm. Biopharm., v.72, n.1, p.91-98, 2009.

PEREIRA, A.V.; GARABELI, A.A.; SCHUNEMANN, G.D.; BORCK, P.C. Determinação da constante de dissociação $\left(\mathrm{K}_{\mathrm{a}}\right)$ do captopril e da nimesulida - Experimentos de química analítica para o curso de farmácia. Quím. Nova, v.34, n.9, p.1656-1660, 2011.

PRAKASH, K.; RAJU, P.N.; KUMARI, K.S.; NARASU, M.L. Solubility and dissolution rate determination of different antiretroviral drugs in different $\mathrm{pH}$ media using UV visible spectrophotometer. E-J. Chem., v.5, n.S2, p.1159-1164, 2008.

REIS, J.M.; DEZANI, A.B.; PEREIRA, T.M.; AVDEEF, A.; SERRA, C.H.R. Lamivudine permeability study: A comparison between PAMPA, ex vivo and in situ singlepass intestinal perfusion (SPIP) in rat jejunum. Eur. $J$. Pharm. Sci., v.48, p.781-789, 2013.

RUELA, A.L.M.; ARAÚJO, M.B.; PEREIRA, G.R. Desenvolvimento de um teste de dissolução para comprimidos de nimesulida em meio que assegure condições sink. Lat. Am. J. Pharm., v.28, n.5, p.661-667, 2009.
SILVA, G.R.; CONDESSA, F.A.; PIANETTI, G.A.; NUNAN, E.A.; CAMPOS, L.M.M. Desenvolvimento e validação de método por cromatografia líquida de alta eficiência para determinação simultânea das impurezas timina e timidina na matéria-prima estavudina. Quím. Nova, v.31, n.7, p.16861690, 2008.

SINGH, S.; DOBHAL, A.K.; JAIN, A.; PANDIT, J.K. CHAKRABORTY, S. Formulation and evaluation of solid lipid nanoparticles of a water soluble drug: zidovudine. Chem. Pharm. Bull., v.58, n.5, p.650-655, 2010.

SOARES, K.C.C.; REDIGUIERI, C.F.; SOUZA, J.; SERRA, C.H.R.; ABRAHAMSSON, B.; GROOT, D.W.; KOPP, S.; LANGGUTH, P.; POLLI, J.E.; SHAH, V.P.; DRESSMAN, $\mathrm{J}$. Biowaiver monographs for immediate-release solid oral dosage forms: zidovudine (azidothymidine). J. Pharm. Sci., v.102, n.8, p.2409-2423, 2013.

SOUZA, J.; FREITAS, Z.M.; STORPIRTIS, S. Modelos in vitro para determinação da absorção de fármacos e previsão da relação dissolução/absorção. Rev. Bras. Ciênc. Farm., v.43, n. 4, p.515-527, 2007.

STRAUCH, S.; JANTRATID, E.; DRESSMAN, J.B.; JUNGINGER, H.E.; KOPP, S.; MIDHA, K.K.; SHAH, V.P.; STAVCHANSKY, S.; BARENDS, D.M. Biowaiver monographs for immediate release solid oral dosage forms: lamivudine. J. Pharm. Sci., v.100, n.6, p.2054-2063, 2011.

UNITED STATES. Department of Health \& Human Services. Food and Drug Administration.Drugs@FDA: FDA approved drug products. Available at: $<$ http://www. accessdata.fda.gov/scripts/cder/drugsatfda/ $>$. Accessed on: 14 Mar. 2012.

UNITED STATES. Department of Health \& Human Services. Food and Drug Administration. Center for Drug Evaluation and Research. Guidance for industry: waiver of in vivo bioavailability and bioequivalence studies for immediaterelease solid oral dosage forms based on a biopharmaceutics classification system. Rockville: FDA, 2000. p.1-13. Available at: <http://www.fda.gov/downloads/Drugs/ GuidanceComplianceRegulatoryInformation/Guidances/ ucm070246.pdf $>$. Accessed on: 20 July 2012.

UNITED States Pharmacopeia 33: The National Formulary 28. Rockville: United States Pharmacopeial Convention, 2010. 
VIEGAS, T.X.; CURATELLA, R.U.; WINKLE, L.L.V.; BRINKER, G. Measurement of intrinsic drug dissolution rates using two types of apparatus. Pharm. Technol., v.25, p.44-53, 2001.

WADKE, D.A.; REIER, G.E. Use of intrinsic dissolution rates to determine thermodynamic parameters associated with phase transitions. J. Pharm. Sci., v.61, n.6, p.868-871, 1972.

WORLD HEALTH ORGANIZATION. Proposal to waive in vivo biequivalence requirements for the WHO model list of essential medicines immediate release, solid oral dosage forms. Geneva: WHO, 2005. Available at: <http://www. who.int/medicines/services/expertcommittees/pharmprep/ QAS04_109Rev1_Waive_invivo_bioequiv.pdf $>$. Accessed on: 10 May 2012.

WORLD HEALTH ORGANIZATION. Who expert committee on specifications for pharmaceutical preparations. Lamivudine: final text for addiction to The International Pharmacopeia. Geneva: WHO, 2006. Available at: $<$ http:// www.who.int/medicines/publications/pharmacopoeia/ QAS_124rev2_Lamivudine.monoFINAL.pdf $>$. Accessed on: 3 July 2012.

WON, D.-H.; KIM, M.-S.; LEE, S.; PARK, J.-S.; HWANG, S.-J. Improved physicochemical characteristics of felodipine solid dispersion particles by supercritical anti-solvent precipitation process. Int. J. Pharm., v.301, n.1-2, p.199208, 2005.
WOOD, J.; SYARTO, J.; LETTERMAN, H. Improved holder for intrinsic dissolution rate studies. J. Pharm. Sci., v.54, n.7, p.1068, 1965.

YU, L.X.; AMIDON, G.L. Analytical solutions to mass transfer. In: AMIDON, G.L.; LEE, P.I.; TOPP, E.M. (Eds.). Transport processes in pharmaceutical systems. New York: Marcel Dekker, 1999. p.23-54.

YU, L.X.; AMIDON, G.L.; POLLI, J.E.; ZHAO, H.; MEHTA, M.U.; CONNER, D.P.; SHAH, V.P.; LESKO, L.J.; CHEN, M.L.; LEE, V.H.L.; HUSSAIN, A.S. Biopharmaceutics classification system: the scientific basis for biowaiver extensions. Pharm. Res., v.19, n.7, p.921-925, 2002.

YU, L.X.; CARLIN, A.S.; AMIDON, G.L.; HUSSAIN, A.S. Feasibility studies of utilizing disk intrinsic dissolution rate to classify drugs. Int. J. Pharm., v.270, n.1-2, p.221227, 2004.

ZAKERI-MILANI, P.; BARZEGAR-JALALI, M.; AZIMI, M.; VALIZADEH, H. Biopharmaceutical classification of drugs using intrinsic dissolution rate (IDR) and rat intestinal permeability. Eur. J. Pharm. Biopharm., v.73, n.1, p.102106, 2009.

Received for publication on $26^{\text {th }}$ January 2013 Accepted for publication on $30^{\text {th }}$ July 2013 